\title{
Performance Characteristics of a Diesel Engine Fuelled with Biodiesel Produced from Mahua Oil Using Additive
}

\author{
Purna C. Mishra ${ }^{1 *}$, Swarup. K. Nayak ${ }^{1}$, Durga. P. Ghosh ${ }^{1}$, Manoj \\ Ukamanal $^{1}$,Sushanta.K. Sahu ${ }^{1}$ \\ ${ }^{I}$ School of Mechanical Engineering, KIIT University, Bhubaneswar - 751024, Odisha, India
}

\begin{abstract}
The demand for consumption of petroleum products increased with vehicles population.For addressing the present problem we discussed alternate fuel. Moreover, the alternate fuel must be produced in such a manner that it can be used directly in present engines without much engine modifications. Edible and non-edible oils are the main source for alternate fuel. In this paper we have discussed the performance characteristics of a diesel engine fuelled with mahua oil using additive. Due to high viscosity and low volatility of non-edible oils their prolonged use is not advisable. These problems can be minimised by the transesterification process which is a reaction of triglyceride and alcohol in presence of a catalyst to produce mono alkyl ester which is known as biodiesel and glycerol. The biodiesel was blended with additive in various proportions to prepare a number of test fuels which are tested on a diesel engine to studyvarious parameters like carbon residue, fire point, flash point, viscosity, pour point, cloud point, cetane index etc. and compare those with that of diesel. The result shows biodiesel with $10 \%$ additive (Dimethyl carbonate) is best suited for diesel engine.
\end{abstract}

Keywords:-Mahua oil, Diesel, Additive, Transesterification, Engine performance

\section{Introduction}

In this century, it is observed that crude oil and its products will become very scare and costly. As the numbers of engines are increasing, the consumption of fuel is also increasing [1]. Therefore, enormous increase in number of vehicles hasled to the depletion of crude oil resources at a steep rate. Diesel will become costly in the near future. The various biomass based resources can be used as an extender or a complete substitute to the diesel fuel in agriculture, industrial or transport sector in energy crisis situation $[2,3]$. The role of diesel in these sectors has been over emphasised. In fact agriculture and transport sector are almost diesel dependant. So, there is a need to search for an alternative fuel that can substitute diesel. The various edible oils like sunflower, soyabean, peanut, cotton seed etc. have successfully tested in diesel engine [4]. Therefore research in the direction for using non-edible like mahua (Madhuca Indica) oil has been tested as diesel fuel extender. Even though the properties of vegetable oil and non-edible oil are close to diesel fuel, but to run diesel engine without any modification usingthese fuels results in severe engine deposits, dilution of lubricating oil with unburnt fuel, injected choking, piston ring sticking etc.. Most of these problems results due to high viscosity and low volatility of edible and non-edible oils [6]. Hence there is a need for a better fuel which can compensate these problems. In this context bio-diesel can be derived from edible and non-edible oil, which serves the purpose. Bio-diesel can be derived from edible and non-edible oil depending on the availability. If we consider the economics of producing bio-diesel from mahua oil then the various by-products obtained have good commercial value. The revenue generated from these by-products shall reduce the overall cost of the bio-diesel [7]. The cost components of bio-diesel are price of seed, seed collection, oil extraction and transesterification. So the cost biodiesel obtained after transesterification process of oil will be close to the cost of the seed required to produce the bio-diesel $[8,9]$.

\section{Transesterification reaction}

Transesterification is a reversible reaction between triglyceride and alcohol in presence of catalyst to produce glycerol and mono alkyl ester which is known as biodiesel $[9,10]$. Weight of the mono alkyl ester is one third of that of typical oil and therefore has lower viscosity. Alkali $(\mathrm{NaOH}, \mathrm{KOH})$, acid $\left(\mathrm{H}_{2} \mathrm{SO}_{4}, \mathrm{HCL}\right)$ or enzymes (lipase) catalyzed reaction. Acid catalyzed transesterification is most commonly used process because it is a reversible reaction [10]. In the transesterification process methanol and ethanol are more common. Methanol is more extensively used due to its low cost and physiochemical advantages with triglycerides and alkali are dissolved in it $[11,12]$. Studies have been carried out in different oils like soyabean, sunflower, jathropa, karanja, neem, etc. Mostly biodiesel is produced by base catalyzed transesterification process of oil and it is more economical. Here the process is a reaction of triglyceride with alcohol to form mono alkyl ester commonly known as biodiesel and glycerol as by product [12]. The main reason for doing titration to biodiesel 
is to find out the amount alkaline needed to completely neutralize any free fatty acid present, thus ensuring a complete transesterification $[13,14]$.

The chemical reaction which describes the preparation of biodiesel is:

$$
\text { Triglyceride }
$$

Fig. 1 Reaction process for transesterification

In this figure R1, R2, R3 represent long carbon chains.

\section{Materials}

\section{Materials And Methods}

\subsection{Mahua (Madhuca Indica)}

The two major species of genus madhuca found in India are Madhuca Indica (Longifolia) and Madhuca Indica (Latifolia). The seed potential of this tree in India is 500,000 tons and oil potential is 180,000 tons.Madhuca latifolia can be from medium size to large deciduous tree, distributed in Andhra Pradesh, Gujarat, Madhya Pradesh, Orissa, Bihar and Uttar Pradesh. Madhuca Longifolia, a large ever green tree found in south Indiaand evergreen forest of the western ghats. It attains a height up to $70 \mathrm{ft}$. The tree matures within 8 to 15 years and fruits up to 60 years. The kernels are $70 \%$ of seed by weight. Oil content in Latifolia is $46 \%$ and $52 \%$ in Longifolia. In seed oil content $35 \%$ and $16 \%$ protein.

\subsection{Dimethyl carbonate}

Di methyl carbonate is a colourless, transparent liquid under normal temperature.

TABLE I

PROPERTIES OF DIMETHYL CARBONATE

\begin{tabular}{|l|l|}
\hline Molecular Formula & $\mathrm{C}_{3} \mathrm{H}_{6} \mathrm{O}_{3}$ \\
\hline Molar mass & $90.08 \mathrm{gm} / \mathrm{mole}$ \\
\hline Appearance & Clear liquid \\
\hline Density & $1.069-1.073 \mathrm{gm} / \mathrm{mole}$ \\
\hline Melting point & $(275-277 \mathrm{~K})$ \\
\hline
\end{tabular}

\section{Methodology}

\section{Heating and Cooling:}

One litre of mahua oil was poured into the glass beaker and placed on heater for heating. Oil was heated above $100^{\circ} \mathrm{c}$ (approximately $115^{\circ} \mathrm{c}$ ) with beaker mouth open to atmosphere and maintained this temperature about 15 minutes, this is done to remove the water particles present in the oil which effect the reactions that are performed on the oil further. Heating was performed with continuous stirring and this is performed by magnetic stirrer which is placed inside the glass beaker in the oil. This is done to avoid formation of large water vapour bubbles inside the beaker which on a sudden evaporation may cause explosion. After this part cool the oil to $45^{\circ} \mathrm{C}-50^{\circ} \mathrm{C}$. Filter the cooled oil with a neat cloth for removing any dust or dirt particles present in it.

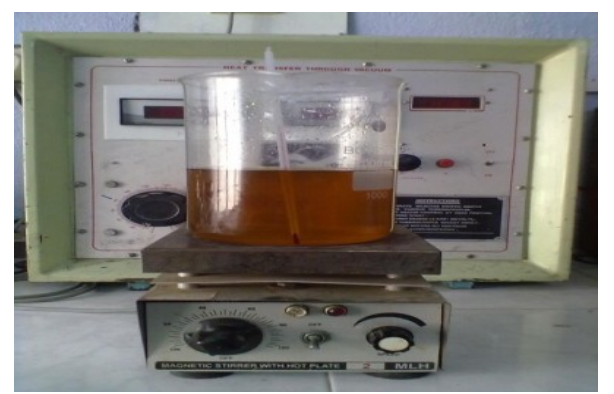

Fig. 2 Preheating of raw mahua oil 


\section{Acid Treatment:}

Add $120-150 \mathrm{ml}$ of $\mathrm{CH}_{3} \mathrm{OH}$ methanol per litre of oil and close the conical flask with rubber stopper, this is done to avoid evaporation of methanol (since the boiling point temperature of methanol is $55^{\circ} \mathrm{C}$ to $60^{\circ} \mathrm{C}$ ). After half an hour add 3-7 ml of $\mathrm{H}_{2} \mathrm{SO}_{4}$ and maintain the temperature between $50^{\circ} \mathrm{C}-55^{\circ} \mathrm{C}$ (should not be more than $60^{\circ} \mathrm{C}$ ). After 1 hour (reaction time) take this liquid into separating flask for 2 or 3 hours later the liquid separates into two immiscible liquids.

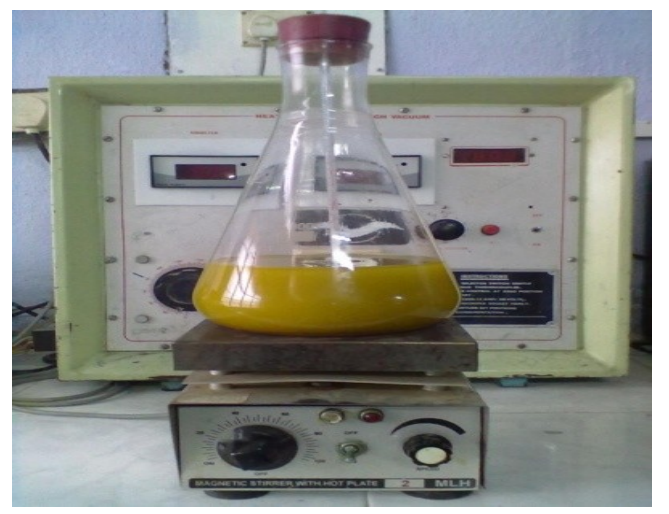

Fig. 3 Acid treatment

\section{Base Treatment:}

Heat the oil to $(40-45){ }^{0} \mathrm{C}$ in the conical flask. Take $200 \mathrm{ml}$ of methanol in round bottom flask and add $6.5 \mathrm{gm}$ of sodium hydroxide pellets and shake well so that there is no solved particle of sodium particles. This forms the sodium methoxide solution. Mix the sodium methoxide with the acid treated oil $\mathrm{n}$ maintains the temperature of $(50-58){ }^{0} \mathrm{C}$ in conical flask. The reaction time is $(1 \mathrm{hr}-11 / 2 \mathrm{hr})$. The temperature should not exceed above $60^{\circ} \mathrm{C}$ as the methanol evaporates above $60^{\circ} \mathrm{C}$ and stirring is done throughout the reaction. The colour of the oil changes from pale yellow to dark brown. Pour the oil in the separating funnel.

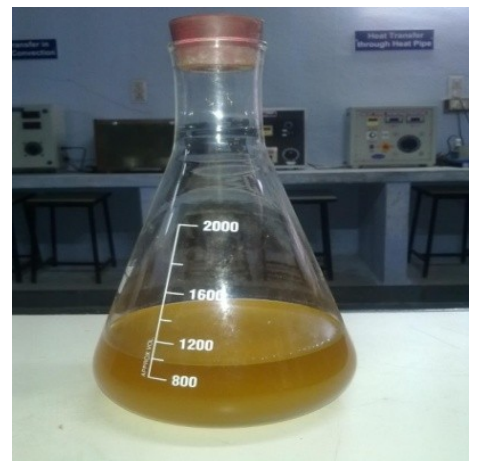

Fig. 4 Base treatment

\section{Settling:}

The oil has been settled for $12 \mathrm{hr}$. we observe the biodiesel at the top of funnel glycerol at the bottom. Remove the glycerol from the bottom of the separating funnel.

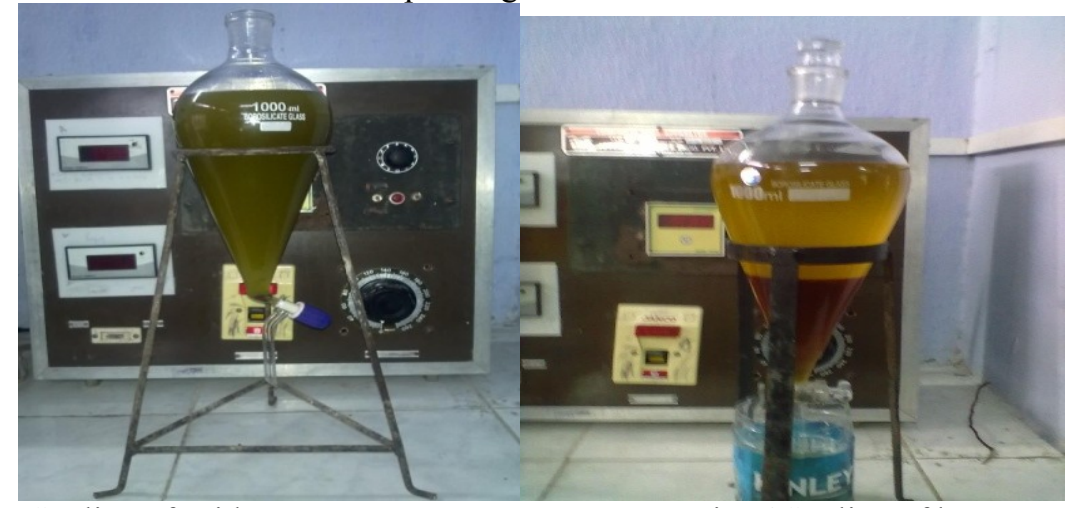

Fig. 5 Settling of acid treatment

Fig. 6 Settling of base treatment 


\section{Water Wash:}

Take the oil into the separating funnel, mix distilled water with oil about half the volume of oil in separating funnel. Add 2 or 3 drops of Ortho-phosphoric acid. Keep bubbling for half an hour and this is repeated a number of times until clear water and oil are visible.

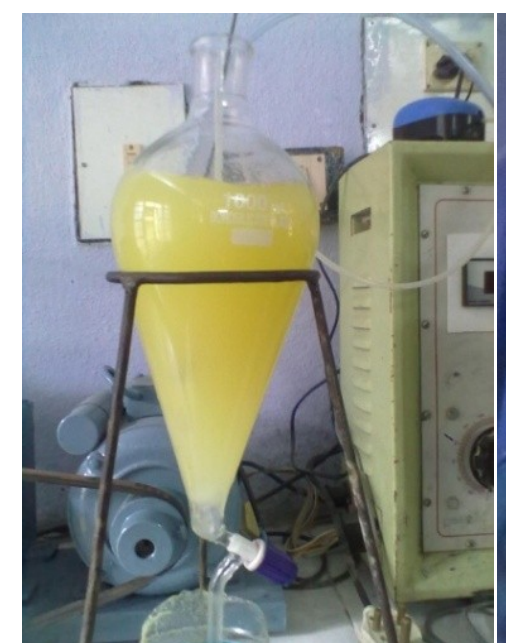

Fig. 7 Water wash

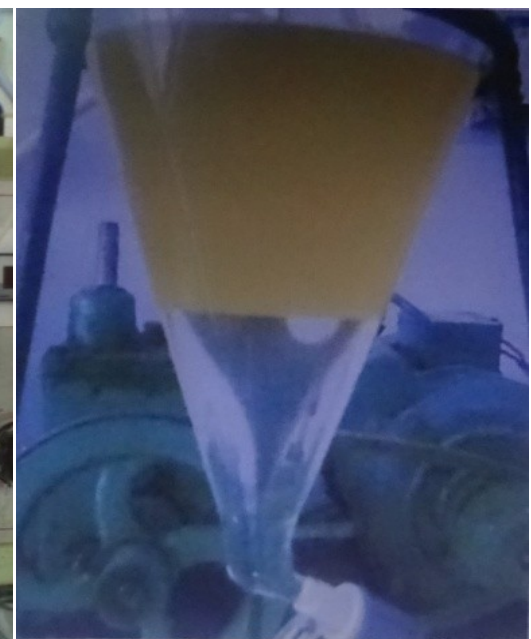

Fig. 8 After water wash

\section{Heating:}

Heat the Biodiesel above $110{ }^{\circ} \mathrm{C}$ (say $115^{\circ} \mathrm{C}$ ) with beaker mouth opened to atmosphere and maintains this temperature for about $15 \mathrm{~min}$. This is done to remove the water particles from biodiesel. Heating should be done with continuous stirring and this is performed my magnetic stirrer which is placed inside the glass beaker in the biodiesel. This is done to avoid formation of large water vapor bubbles inside the beaker which on sudden evaporation may cause explosion.

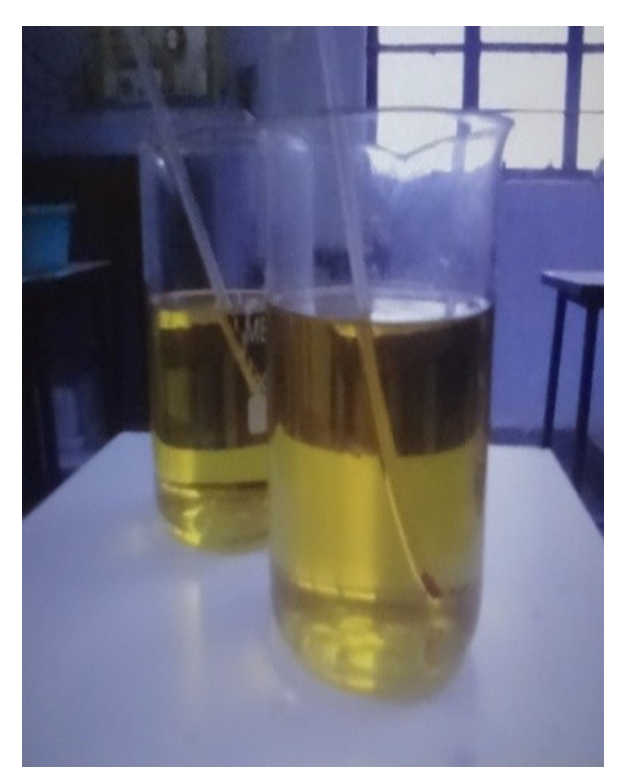

Fig. 9 Pure biodiesel 


\section{Flow Chart Representation}

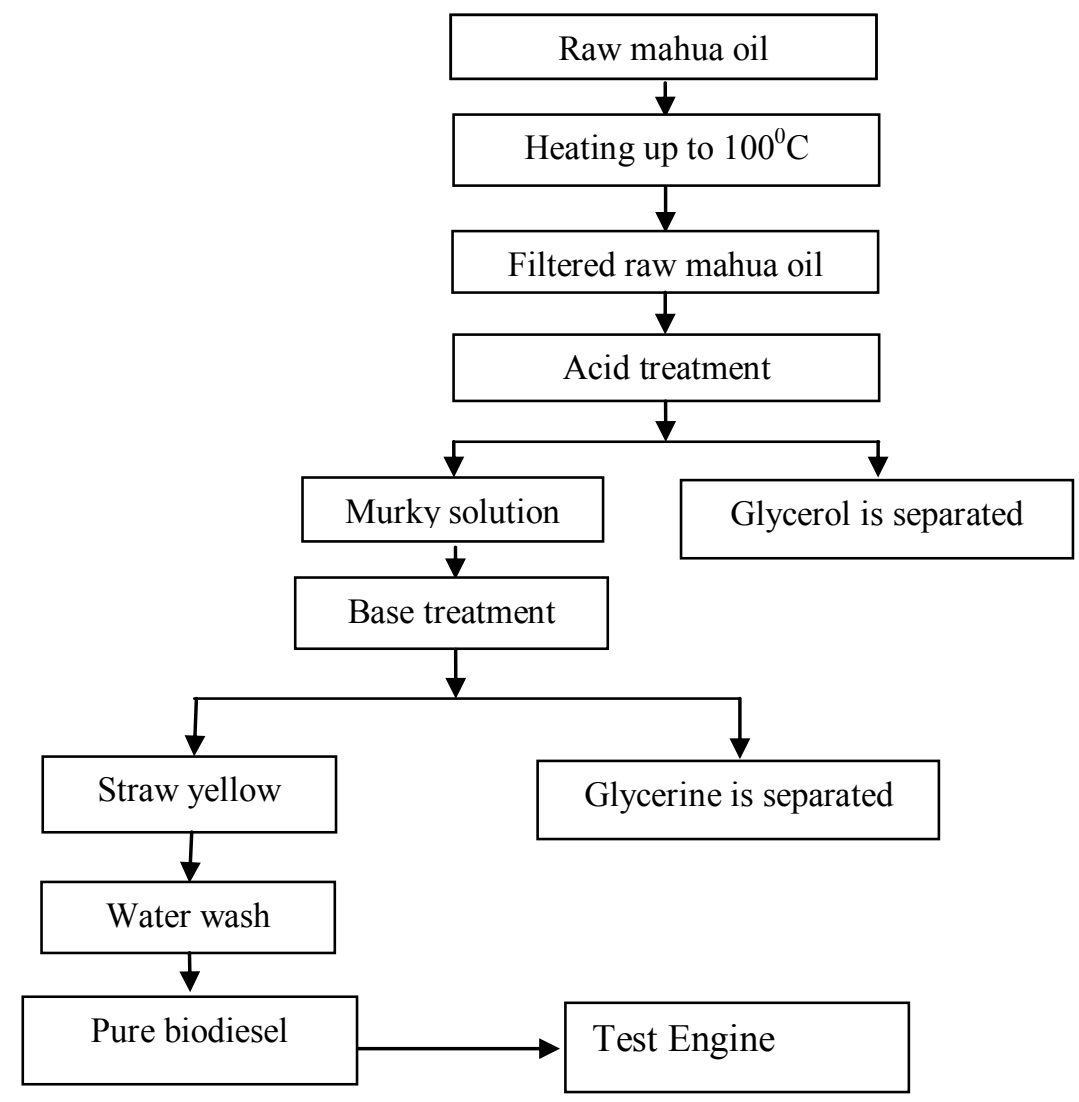

Fig. 10 Flow chart for mahua oil methyl ester preparation.

TABLE II

PARAMETERS OF THE PROCESSES

\begin{tabular}{|c|l|l|}
\hline Sl.No & \multicolumn{1}{|c|}{ Process parameters } & \multicolumn{1}{c|}{ Description } \\
\hline 1 & Process selected & Alkali catalyzed transesterification \\
\hline 2 & Volume of oil being used & $1000 \mathrm{ml}$ of raw mahua oil \\
\hline 3 & Reaction temperature & $50-55^{0} \mathrm{C}$ \\
\hline 4 & Methanol used & $120 \mathrm{ml} / \mathrm{kg}$ of oil \\
\hline 5 & Catalyst used & $\mathrm{KOH}, 0.5-1 \%$ per $\mathrm{kg}$ of oil \\
\hline 6 & Stirring speed & $500 \mathrm{rpm}$ \\
\hline 7 & Reaction time & $1.5-2$ hours \\
\hline 8 & Settling time & $8-10$ hours \\
\hline 9 & Water wash & $4-5$ times $(40 \mathrm{~min})$. \\
\hline
\end{tabular}

3. Characteristics of test fuels

TABLE III

COMPARISON OF FUEL PROPERTIES FOR DIESEL AND BIODIESEL

\begin{tabular}{|l|l|l|l|l|}
\hline Sl.No & Properties of fuel & Unit & Diesel & Biodiesel \\
\hline 1 & Kinematic viscosity at 400C & cSt. & 4.57 & 5.39 \\
\hline 2 & Specific gravity at 150C & - & 0.8668 & 0.8712 \\
\hline 3 & Flash point & $0 \mathrm{C}$ & 42 & 157 \\
\hline 4 & Fire point & $0 \mathrm{C}$ & 68 & 183 \\
\hline 5 & Pour point & $0 \mathrm{C}$ & -18 & 2 \\
\hline 6 & Cloud point & $0 \mathrm{C}$ & -3 & 16 \\
\hline 7 & Cetane index & - & 50.6 & 51.2 \\
\hline 8 & Calorific value & $\mathrm{KJ} / \mathrm{Kg}-\mathrm{K}$ & 42850 & 42293 \\
\hline
\end{tabular}




\section{Test Engine}

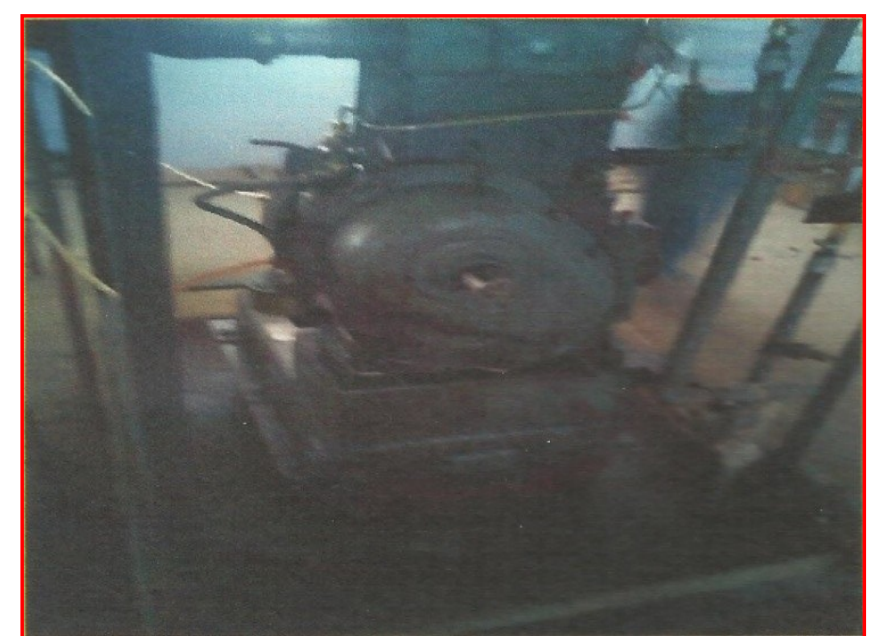

Fig. 11 Picture of the test engine

TABLE IV

ENGINE SPECIFICATION

\begin{tabular}{|c|l|l|}
\hline Sl.No & Particulars & Description \\
\hline 1 & Engine type & Single cylinder, 4-stroke. vertical water cooled diesel engine \\
\hline 2 & Bore diameter & $80 \mathrm{~mm}$ \\
\hline 3 & Stroke length & $110 \mathrm{~mm}$ \\
\hline 4 & Compression ratio & $16: 1$ \\
\hline 5 & Rated power & $3.67 \mathrm{KW}$ \\
\hline 6 & Rated speed & $1500 \mathrm{rpm}$ \\
\hline 7 & Dynamometer & Rope brake dynamometer \\
\hline
\end{tabular}

The test bed consists of diesel engine, mechanical dynamometer, dead weight for loading the engine (in $\mathrm{kg}$ ), hand tachometer to measure the speed (rpm), orifice meter in conjunction with U-tube manometer measuring volume flow rate of air, graduate burette for volume flow rate of fuel in cc and measuring jar for measuring cooling water flow rate $[15,16]$. The prepared bio-diesel is poured into the cylindrical tank. Then the level of fuel and lubricating oil is checked. The 3-way cock is opened so that the fuel flows to the engine. Cooling water is supplied through the inlet pipe [17]. The engine is then started with the supply of the fuel. The speed of the engine is kept constant for varying load conditions i.e. $\mathrm{N}=1500 \mathrm{rpm}$. The observation included manometerreading, time taken for $20 \mathrm{cc}$ of fuel consumption, load at which reading is taken, inlet and outlet temperature of water and the exhaust gas temperature [18]. The readings were noted down carefully with respect to load applied on the engine and blend composition of bio-diesel with additive. The above procedure is repeated for bio-diesel with different proportion of additive blend with the bio-diesel. Now engine parameters are found for different load condition i.e. $3 \mathrm{~kg}, 6 \mathrm{~kg}, 9 \mathrm{~kg}$ and $12 \mathrm{~kg}$. These values that were obtained from testing bio-diesel were used to determine the engine parameters in order to find the performance of the C.I. engine $[19,20]$ 
III. Results And Discussion

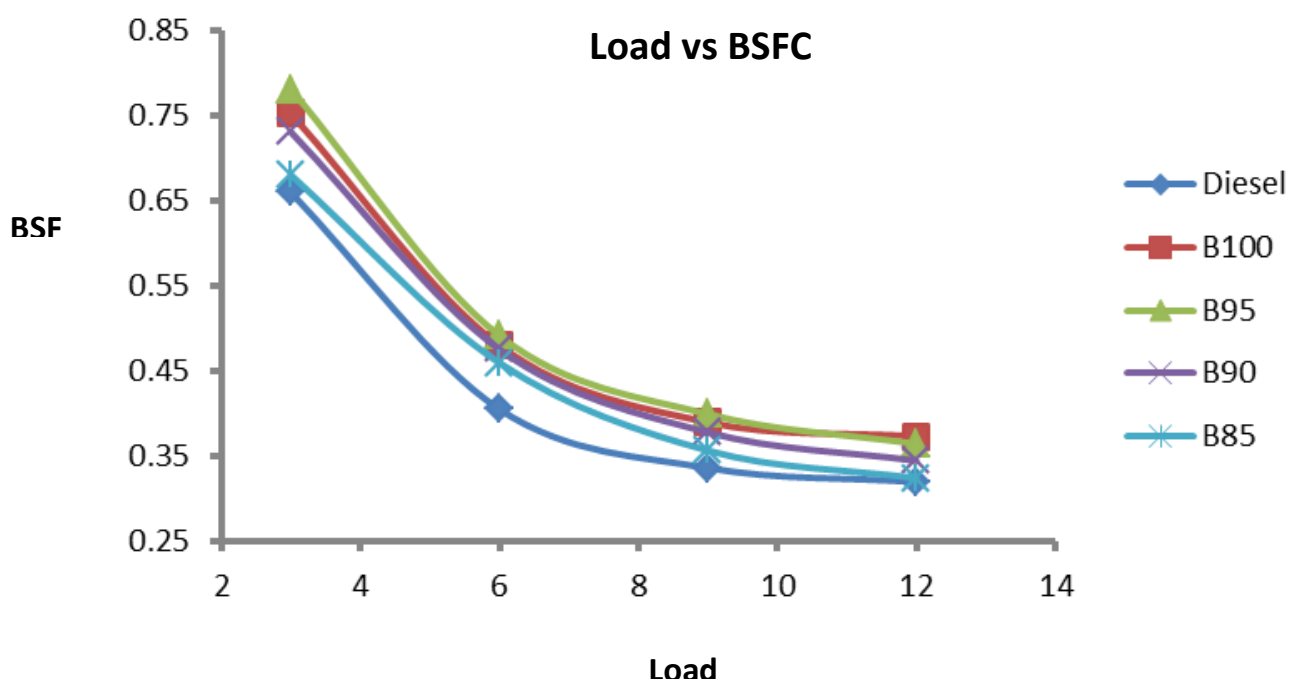

Fig. 12 BSFCwith Load

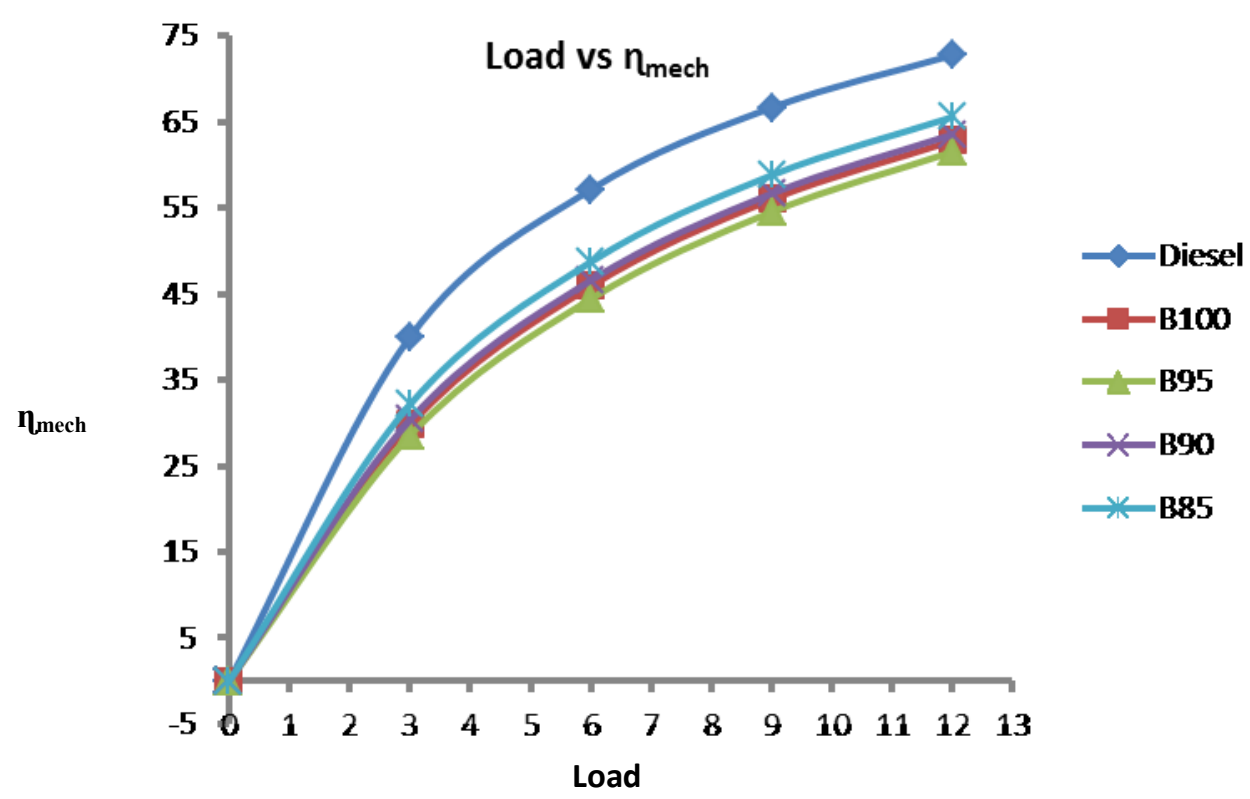

Fig. $13 \eta_{\text {mech }}$ with Load

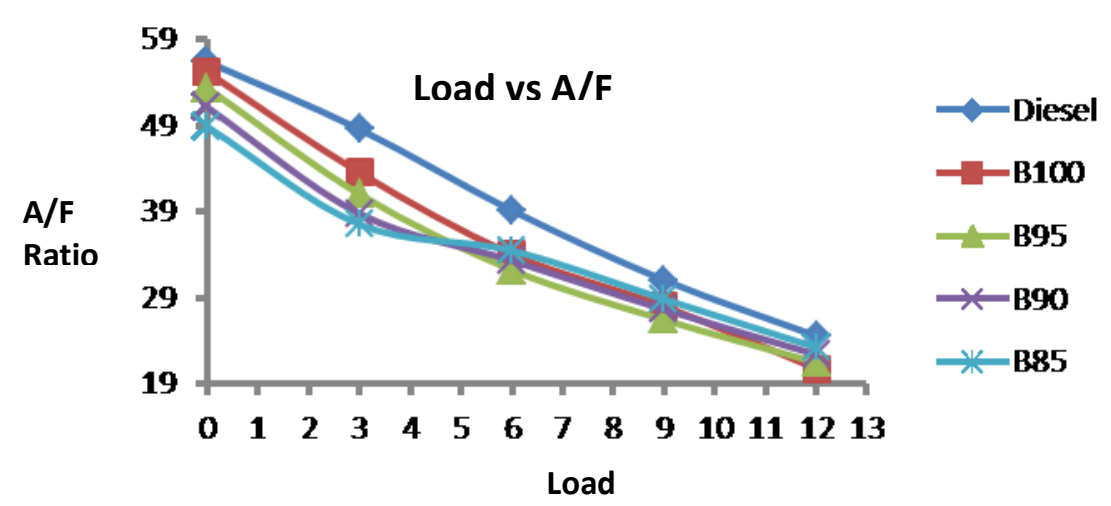

Fig. 14 A/F Ratiowith Load 


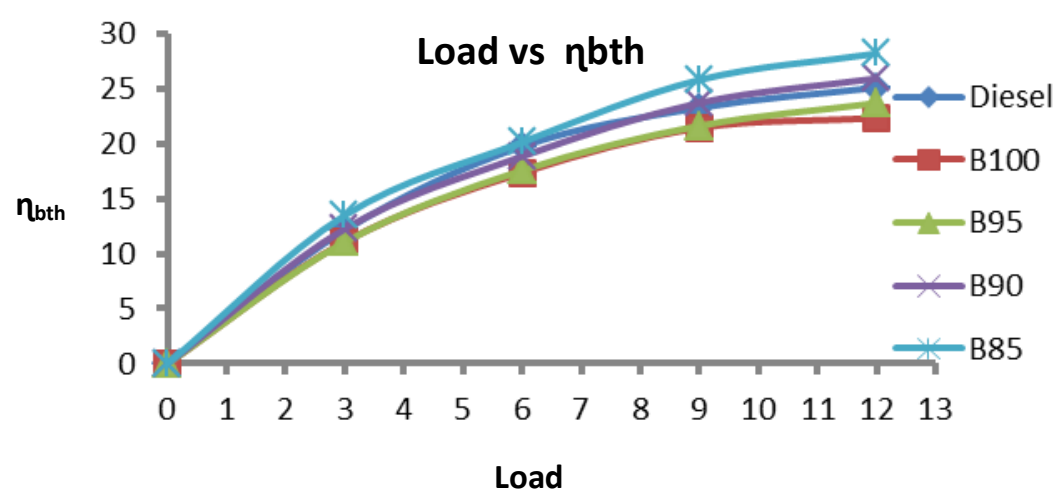

Fig. $15 n_{\text {bth }}$ with Load

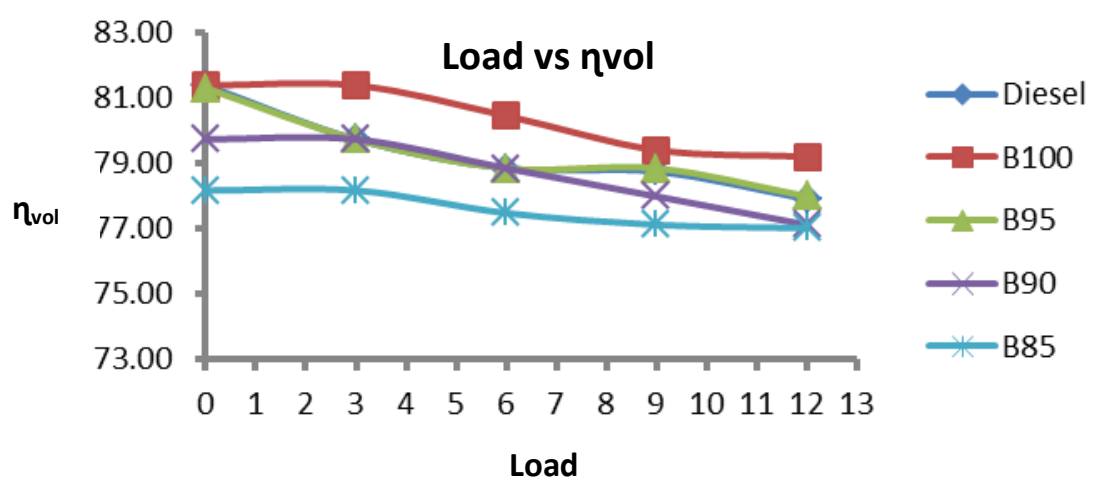

Fig. $16 \eta_{\text {yol }}$ with Load

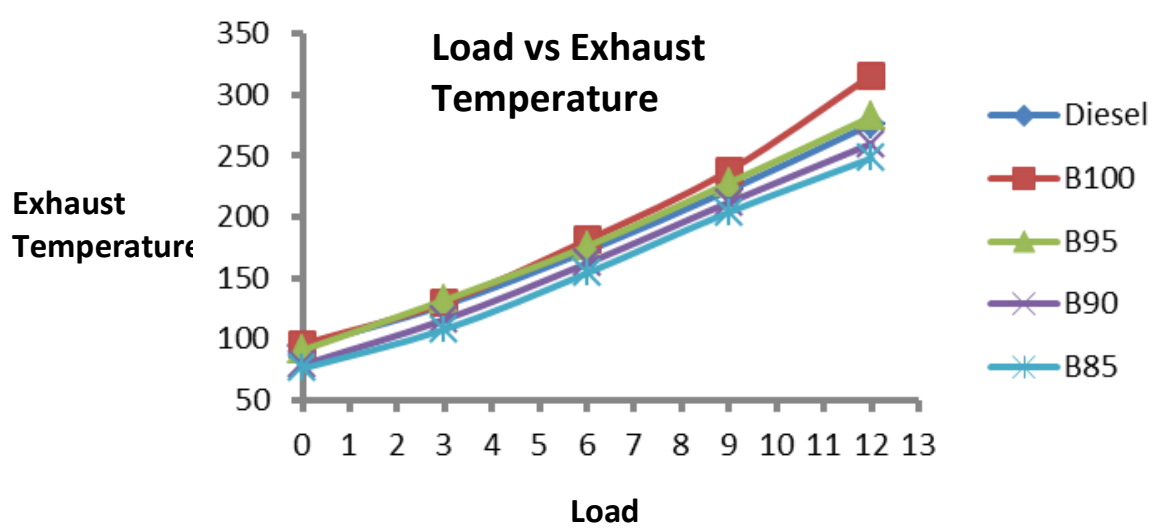

Fig. 17Exhaust Temperaturewith Load

From Fig. 12 brake specific fuel consumption with load, we observed that diesel is more economic when compared with all test fuels which may be due to higher density and viscosity of biodiesel. More the composition of additive more is the BSFC.

From Fig. 13 mechanical efficiency with load, we observe that biodiesel has highest mechanical efficiency when compared with rest of the test fuels.

From Fig. 14 air fuel ratio with load, we observed that diesel has highest air fuel ratio when compared with rest of the test fuels which may be due to higher density and viscosity of biodiesel.

From Fig. 15 brake thermal efficiency with load, we find that B85 has better thermal efficiency than that of all other test fuels .

From Fig. 16volumetric efficiency with load, we observed that pure bio-diesel has highest equivalence ratio when compared with all the test fuels.

From Fig. 17 exhaust temperature with load, we observed that diesel has less exhaust temperature when compared with all other test fuels. Biodiesel has highest exhaust temperature because of highest oxygen content. 


\section{Conclusion}

From above discussion we conclude that:-

1. $\quad$ Pure diesel has less exhaust temperature when compared with all other test fuels.

2. Bio-diesel with $15 \%$ additive has better thermal efficiency than that of all other test fuels.

3. Diesel has lowest BSFC when compared with all test fuels.

4. Pure bio-diesel has highest equivalence ratio when compared with all the test fuels.

5. Diesel has highest mechanical efficiency when compared with rest of the test fuels.uk

6. Diesel has highest air fuel ratio when compared with rest of the test fuels.

\section{Reference}

[1] R. K. Pandey, A. Rehman, R.M. Sarviya and S. Dixit, Development of clean burning fuel for compression ignition engines, Asian J. exp. Sci, 23(1), 223-234, 2009

[2] R.K Singh and S.K Padhi, Characterization of jathropa oil for the preparation of biodiesel, Natural product radiance, 8(2), 127-132, 2009

[3] H.Mulimani, Dr. O.D. Hebbal and M. C. Navindgi, Extraction of biodiesel from vegetable oil and their comparisons, International journal of advance scientific research and technology, 2(2), 242-250, 2012

[4] S. K Padhi and R. K. Singh, Non-edible oil as the potential source for the production of biodiesel in india: A review, J. Chem. phar. Res., 3(2), 39-49, 2011

[5] B.K Mishra and Dr. R. Kumar, The production of biodegradable fuel from non-edible oil seed in India: A Review, IOSR journal of applied chemistry, 1(1), 43-46, 2012

[6] P.P. Sonune and H.S. Farkade, Performance and emission of C.I engine fuelled with pre heated vegetable oil and its blend: A Review, International journal of engineering and innovative technology, 2(3), 123-127, 2012

[7] M.R. Heyderiazad, R. Khatibinasab, S. Givtaj and S. J. AmadiChatabi, Biofuels production process and the net effect of biomass energy production on the environment, World renewable energy congress, 524-529, 2011

[8] M. Pugazhvadivu and G. Sankaranarayana, Experimental studies on a diesel engine using mahua oil as fuel, Indian journal of science and technology, 3(7), 787-791, 2010

[9] A.F. Sherwani, A.K Yadav and M. W. Karimi, Experimental study on the performance and emission characteristics of a four stroke diesel engine running with mahua oil methyl ester, 2(2315-4721), 80-84, 2013

[10] N. Shrivastava, S.N Varma and M. Pandey, Experimental study on the production of karanja oil methyl ester and its effect on diesel engine, Int. journal of renewable energy developement, 1(3), 115-122, 2012

[11] M.K. Ghosal, D.K Das, S.C. Pradhan and N. Sahoo, Performance study of diesel engine by using mahua methyl ester (biodiesel) a nd its blend with diesel fuel, Agricultural engineering international: the CIGR E journal, 10, 1-9, 2008

[12] M. Kumar and O. Singh, Study of biodiesel as fuel for C I engines and its environmental sffects: A research review, International journal of advances in engineering and technology, 5(2), 100-107, 2013

[13] S.S Rajit, S.K Mohapatra and K. Kundu, Performance and emission evaluation of a diesel engine fuelled with methyl ester of neem oil and filtered neem oil, Journal of scientific and Industrial research, 69, 62-66, 2010

[14] A. H. Lenin, R. Ravi and K. Thyagarajan, Performance characteristics of a diesel engine using mahua biodiesel as alternate fuel, Iranica journal of energy and environment, 4(2), 136-141, 2013

[15] H. Raheman and S. V Ghadge performance of compression ignition engine with mahua ( madhuca indica) biodiesel, Elsevier, Fuel, $86,2568-2573,2007$

[16] S. Puhana, N. Vedaraman, Bojanna V. B. Ram, G. Sankaranarayana and K. Jaychandran, Mahua oil (madhuca indica seed oil) methyl ester used as biodiesel preparation and emission characteristics, Biomass and bioenergy, 28, 87-93, 2005

[17] S. Godiganur, Performance and emission characteristics of a kirloskar HA394 diesel engine operated on mahua oil ,ethyl ester, Thammasat int. J. Sc. Tech., 15, 2010

[18] S. Puhan, N. Vedaraman, B.V. Rambrahaman and G. Nagrajan, Mahua (Madhuca Indica) seed oil : A source of renewable energy in India, Journal of thermal science and Industrial research, 64, 2005, 890-896

[19] S. Savariraj, T. Ganpathy and C.G. Saravanan, Research article Experimental investigation of performance and emission characteristics of mahua biodiesel in diesel engine, International scholarly research network, 10, 2011, 1-6

[20] D. Bajpai and V.K. Tyagi, Biodiesel: source, production, composition properties and its benefits, Journal of OLEo science, 55(10), 2006, 487-502 